\title{
Chemical characterization of the Allium sativum and Origanum vulgare essential oils and their inhibition effect on the growth of some food pathogens
}

\author{
MALLET, A.C.T. $;$ CARDOSO, M.G. ${ }^{*}$; SOUZA, P.E. ${ }^{3}$; MACHADO, S.M.F. ${ }^{4}$; ANDRADE, M.A. ${ }^{2}$; NELSON, D.L. ${ }^{5}$; \\ PICCOLI, R.H. ${ }^{1}$; PEREIRA, C.G. ${ }^{1}$ \\ ${ }^{1}$ Departamento de Ciência dos Alimentos 2 Departamento de Química *mgcardoso@ dqi.ufla.br ${ }^{3}$ Departamento de \\ Fitopatologia Universidade Federal de Lavras, Caixa Postal 3037, CEP: 37200-000, Lavras-Brazil " Departamento \\ de Química, Universidade Federal de Sergipe, CEP: 49100-000, Aracaju-Brazil ${ }^{5}$ Departamento de Alimentos, \\ Faculdade de Farmácia, Universidade Federal de Minas Gerais, CEP: 31270-901, Belo Horizonte-Brazil
}

\begin{abstract}
This study sought to evaluate the chemical composition of the Allium sativum and Origanum vulgare essential oils and their effect on the growth inhibition of microorganisms, such as $P$. aeruginosa, S. Choleraesuis, $A$. flavus, $A$. niger and $P$. simplicissimum, important food contaminants. The main constituents of the oregano essential oil were 4-terpineol $(27.03 \%)$, $\gamma$-terpinene $(20.04 \%)$, and $\beta$-cymene $(6.34 \%)$, and the main constituents of the garlic essential oil were diallyl trisulfide $(38,81 \%)$, diallyl disulfide $(25.23 \%)$, and methyl allyl trisulfide $(12.52 \%)$. Inhibition zones were formed in in vitro tests on the bacteria $S$. Choleraesuis and $P$. aeruginosa, except for $A$. sativum against $P$. aeruginosa. The inhibition of mycelial growth caused by the oregano essential oil occurred with the concentrations of $0.10,0.03$ and $0.05 \mathrm{mg} \mathrm{mL}^{-1}$ for the $A$. flavus, $A$. niger and $P$. simplicissimum fungi, respectively. The $\mathrm{CMI}$ for the garlic oil began at the $0.03 \mathrm{mg} \mathrm{mL}^{-1}$ concentration for all species of fungi. The oils presented an inhibitory effect against the microorganisms studied and constitute an alternative for microbiological control in food.
\end{abstract}

Keywords: essential oil, food contaminants, chemical composition.

\begin{abstract}
RESUMO: Caracterização química e efeito inibitório dos óleos essenciais de Allium sativum e Origanum vulgare frente ao crescimento de alguns patógenos de alimentos. Objetivou-se avaliar a composição química e o efeito inibitório dos óleos essenciais de Allium sativum e Origanum vulgare frente ao crescimento dos micro-organismos Pseudomonas aeruginosa, Salmonella Choleraesuis, Aspergillus flavus, Aspergillus niger e Penicillium simplicissimum, importantes patógenos causadores de contaminações em alimentos. Para quantificação e identificação dos constituintes químicos dos óleos, utilizou-se cromatógrafo gasoso acoplado a espectrômetro de massas. Os principais constituintes do óleo essencial de orégano foram o 4-terpineol $(27,03 \%)$, $y$-terpineno $(20,04 \%), \beta$-cimeno $(6,34 \%)$, e do alho, o dialil trissulfeto $(38,81 \%)$, dialil dissulfeto $(25,23 \%)$, metil alil trissulfeto $(12,52 \%)$. Os resultados dos testes in vitro sobre as bactérias $S$. Choleraesuis e $P$. aeruginosa indicaram a formação de halo de inibição e revelaram o efeito inibitório para os referidos óleos, exceto para o óleo de $A$. sativum frente a $P$. aeruginosa. Para os fungos $A$. flavus, $A$. niger e $P$. simplicissimum a inibição do crescimento micelial provocada pelo óleo essencial de orégano ocorreu a partir das concentrações de 0,10, 0,03 e 0,05 $\mu \mathrm{g} \mathrm{mL}^{-1}$, respectivamente, sendo que a CMI para o óleo de alho iniciou-se a partir da concentração $0,03 \mu \mathrm{g} \mathrm{mL}^{-1}$ para todas as espécies de fungos. Foi possível verificar que os óleos possuem efeito inibitório sobre os microrganismos estudados, sendo, portanto, uma alternativa no controle microbiológico de alimentos.
\end{abstract}

Palavras-chave: óleo essencial, contaminantes alimentares, constituição química

\section{INTRODUCTION}

It is essential that measures be taken during food production to ensure that the safety and stability of the final products be ensured

throughout the life of the product. The preservation processes have become more complex over the years because the continuous appearance of

Recebido para publicação em 22/11/2010 
new foods in the market requires a longer shelf life and because there exists a high potential for contamination by pathogenic and/or deteriorating microorganisms. Thus, the plant elements that possess antimicrobial properties have received emphasis for possible use in food conservation (Kizil \& Sogut, 2003). Research on plants has created wide interest because of the great diversity of the natural products, which is much greater than that of synthetic products, and because of their possible antimicrobial activities.

The investigation of the antimicrobial activity of plant products has been increasing. Various antimicrobial compounds have been extracted from plants, and the essential oils have been the principal objects of study (Siqui et al., 2000). In view of their prominent antimicrobial properties, they are viable for use in food preservation. Thus, these metabolites have a potential for use in the food industry, where risk of contamination is great. According to Sridhar et al. (2003), essential oils are known to contain a natural blend of monoterpenes and sesquiterpenes, with a variety of functional groups that lead to antifungal and antibacteial properties.

Fungi are one of the major natural degraders of organic matter. They have the ability to grow on various substrates and can cause huge economic losses. According to Pasin et al. (2002), some fungi have the ability to produce toxic substances, mycotoxins, which can cause severe poisoning to humans when present in food.

In view of this scenario, there is a need to create new alternatives for microbiological control of food that could be applied in combination with existing methods. Accordingly, the aromatic species Allium sativum and Origanum vulgare, commonly known as garlic and oregano, either fresh or dried, present an interesting source of antimicrobial agents whose properties are of great value to industries in general.

The present study sought to evaluate the chemical composition of the essential oils from Allium sativum and Origanum vulgare and their inhibitory activities against the growth of the microorganisms Pseudomonas aeruginosa, Salmonella Choleraesuis, Aspergillus flavus, Aspergillus niger and Penicillium simplicissimum.

\section{MATERIAL AND METHOD}

The plant materials were purchased at the Central Market in Belo Horizonte, MG, Brazil, in March 2008. The Allium sativum ("Soeto" brand " lot 460130807) used for extractions was in the form of dehydrated flakes and Origanum vulgare ("Pirata Especiarias" brand, lot F5L B3EO) in its dried form.

\section{Obtaining the essential oils}

The extraction of the essential oils from the plant material was performed at the Laboratory of Organic Chemistry, Department of Chemistry, Federal University of Lavras (UFLA) by steam distillation using a modified Clevenger apparatus. The material was packed in six-liter flasks, and the oil was removed by steam distillation over a twohour period. The distillate was collected and was centrifuged at $321.8 \mathrm{~g}$ for five minutes. The yield was expressed as volume of oil per unit weight of fresh leaves (\% v/w) on a dry weight basis (\% v/w BLU) (Pimentel et al., 2006).

\section{Chemical characterization}

The qualitative analysis of the essential oils was performed at the Department of Chemistry, Federal University of Sergipe (UFS), Aracaju, SE, Brazil, by gas chromatography (GC/MS). A Shimadzu model GC-17 gas chromatograph equipped with a model QP5050A mass-selective detector was employed. The equipment was operated under the following experimental conditions: fused-silica capillary column $(3.0 \mathrm{~m} \times 0.25 \mathrm{~mm})$ with a BDSMS bound stationary phase (Folsom, CA, USA), the temperature of the ion source was $280^{\circ} \mathrm{C}$; the column temperature was programmed with an initial temperature of $50^{\circ} \mathrm{C}$ for $2 \mathrm{~min}$, an increase of $4^{\circ} \mathrm{C}$ $\mathrm{min}^{-1}$ to $200^{\circ} \mathrm{C}$, then $10^{\circ} \mathrm{C} \mathrm{min}^{-1}$ to $300^{\circ} \mathrm{C}$, finalizing at $300^{\circ} \mathrm{C}$ for 10 minutes. The carrier gas was helium (1 $\left.\mathrm{mL} \mathrm{min}^{-1}\right)$; the initial column pressure was 100.2 $\mathrm{kPa}$, the split ratio was $1: 83$; and the injected volume was $0.5 \mathrm{~mL}$ ( $1 \%$ solution in dichloromethane). The configuration of the mass spectrometer (MS) included an impact energy of $70 \mathrm{EV}$; decomposition rate $=1000$; and decomposition interval of 0.50 . Fragments from m/z 40 to $550 \mathrm{Da}$ were recorded. A series of hydrocarbon standards $\left(\mathrm{C}_{9} \mathrm{H}_{20}\right.$ to $\left.\mathrm{C}_{26} \mathrm{H}_{54}\right)$ was injected under the same conditions as the sample. The quantitative analysis was performed at the Laboratory of Organic Chemistry, Federal University of Lavras, using a Shimadzu model GC-17 gas chromatograph equipped with a flame ionization detector (FID) under the following operating conditions: DB5 capillary column containing 35\% phenylmethylpolysiloxane, initial temperature of $45^{\circ} \mathrm{C}$, programmed to $240^{\circ} \mathrm{C}$, injector temperature, $200^{\circ} \mathrm{C}$, FID detector temperature, $240^{\circ} \mathrm{C}$, nitrogen carrier gas (2.2 mL min-1), split ratio, 1:10; injected volume, $1 \mathrm{~mL}$ ( $1 \%$ solution in dichloromethane); column pressure of $115 \mathrm{kPa}$. The quantity of each constituent was obtained by normalization of areas $(\%)$.

\section{Antibacterial Activity}

The microbiological tests for determining the susceptibility of microorganisms to the essential 
oils were performed at the Laboratory of Food Microbiology, Department of Food Science, Federal University of Lavras. Strains of Pseudomonas aeruginosa ATCC 15442 and Salmonella Choleraesuis ATCC 6539 were employed to evaluate the in vitro inhibitory effect of the essential oils of A. sativum (garlic) and O. vulgare (oregano). The organisms were maintained at $4{ }^{\circ} \mathrm{C}$ in Eppendorff tubes containing freezing medium. The counting of the number of colony-forming units was standardized by employing the McFarland scale $(0.5 \%)$ with an inoculum concentration of $10^{6} \mathrm{CFU} \mathrm{mL-1}$. For the activation of the cultures, they were subcultured in brain heart infusion broth (BHI, Oxoid) and incubated for 24 hours at $37^{\circ} \mathrm{C}$. Aliquots were transferred to TSB (Triptic Soy Broth) and incubated again at the same temperature. The increase in the number of microbial cells was monitored every half hour using a spectrophotometer (UV Shimatzu - 160 1PC) at $625 \mathrm{~nm}$ until the reading reached or exceeded the reading of the $0.5 \%$ McFarland solution (NCCLS, 2003). The method employed was that of diffusion in an agar cavity using the Mueller Hinton Agar culture media. This medium was inoculated with cultures ( $P$. aeruginosa and $S$. Choleraesuis) and deposited on the same agar layer where the slots were prepared with the aid of glass beads. These slots were filled with the essential oils diluted in dimethylsulfoxide (DMSO) at concentrations of 500, 250, 125, 62.5, $31.25,15.62,7.81,3.90$ and $1.95 \mu \mathrm{L} \mathrm{mL}$. The plates were incubated in a BOD at $37^{\circ} \mathrm{C}$ for 48 hours (Ogunwande et al., 2005), and the diameters of the halos were measured. A randomized block design with bacteria ( $P$. aeruginosa and $S$. Choleraesuis) as the block factor was employed for statistical analysis, where the factorial design was $2 \times 9 \times 2$ [two essential oils (garlic and oregano), nine concentrations (500, $250,125,62.5,31.25,15.62,7.81,3.90$ and $1.95 \mu \mathrm{L}$ $\mathrm{mL}^{-1}$ ), totaling 18 treatments with three replicates]. The SISVAR program was used for statistical analysis (Ferreira, 2000). The analysis of variance of the treatments utilized the Scott-Knott test at the $5 \%$ significance level.

\section{Antifungal Activity}

Evaluation of the antifungal activity of the garlic and oregano oils was performed at the Laboratory of Epidemiology and Management of the Department of Plant Pathology at the Federal University of Lavras. The pathogens were obtained from the mycology laboratory of the Department of Plant Pathology and registered with the following numbers: Aspergillus niger, CML № 1815; Aspergillus flavus, CML № 1816 and Penicillium simplicissimum, CML № 1817.

The in vitro bioanalytical method was employed whereby the effect of the garlic and oregano oils on the growth of mycelial pathogens was evaluated. Petri dishes $9.0 \mathrm{~cm}$ in diameter were used. The oil concentrations were $0.03,0.05$, $0.07,0.10,0.12,0.14,0.16$ and $0.18 \mathrm{~g} \mathrm{~mL}^{-1}$. Two additional plates, one being the absolute control (containing only the pathogen), and one the relative control (containing only $0.25 \mathrm{~mL}$ of ether on a paper disk attached to the top of the Petri dish) were prepared. Both trials were conducted in triplicate. The PDA (potato-dextrose-agar) culture medium was used. After solidification of the culture medium in the Petri dishes, mycelia of fungus cultures were transferred from a pure culture and placed in the center of the plates. The respective solutions of essential oil were added, and the plates were incubated in a BOD chamber at approximately $25^{\circ} \mathrm{C}$ for seven days.

The measurements of pathogen growth were performed seven days after initiating the experiment, utilizing the means of the perpendicular diameters of the mycelial growth. The percentage of inhibition of growth was calculated for each dose and compared to that of the absolute control (Lindsey \& Standen, 2004). Statistical analyses were accomplished using the SISVAR program (Ferreira, 2000). The treatments were arranged in a completely random manner, with three replicates, and the means were compared by the Scott-Knott test at a 5\% significance level.

TABLE 1. Principal components present in the essential oil of $O$. vulgare.

\begin{tabular}{ccccc}
\hline Peak & $\begin{array}{c}\text { Retention time } \\
(\mathbf{m i n})\end{array}$ & IKcal 1 & Compound & Mean concentration \%) \\
\hline 1 & 7.74 & 1119 & a-terpinene & 10.51 \\
2 & 9.24 & 1061 & Y-terpinene & 20.04 \\
3 & 10.717 & xxxx & B-cymene & 6.34 \\
4 & 14.060 & 1187 & 4-terpineol & 27.03 \\
5 & 19.000 & 1295 & Carvacrol & 4.22 \\
\hline
\end{tabular}

${ }^{1}$ IKcal - Kovats indexes

The chromatogram obtained for O. vulgare is presented in Figure 1.

Rev. Bras. Pl. Med., Campinas, v.16, n.4, p.804-811, 2014. 


\section{RESULT AND DISCUSSION}

About 30 compounds, $86.46 \%$ of the total composition of the oregano oil, were identified by gas chromatography combined with mass spectrometry (CG/FID). The principal compounds present in the essential oil of $O$. vulgare are presented in Table 1, together with their Kovats indexes, retention times, and mean compositions.

The principal constituents identified and quantified from the essential oil of $O$. vulgare were 4-terpineol (27.03\%), y-terpinene (20.04\%), $\beta$-cymene $(6.34 \%)$, carvacrol $(4.22 \%)$, linalool (4.61\%), a-terpineol (3.34\%), o-cymene $(2.77 \%)$, and terpinene $(2.09 \%)$. These compounds were identified by comparison with the Kovats indexes (Adams, 2007).

Pereira et al. (2008), researching the constituents of the essential oil from oregano, identified a total of 19 compounds. Among them were $0.7 \%$ of $\alpha$-pinene, $1.1 \%$ a-phellandrene, $2.7 \%$ myrcene, $6.9 \%$ a-terpinene, $4.6 \%$ p-cymene, $2.3 \% \beta$-phellandrene, $16.6 \%$ o-cymene, $16.0 \%$ $\mathrm{Y}$-terpinene, $1.8 \%$ terpinolene, $12.3 \%$ linalool, $26.3 \%$ 4-terpenol, 3.8\% a-terpineol, 0.8\% thymol methyl ether, $1.6 \%$ carvacrol methyl ether, $7.2 \%$ carvacrol and $1.3 \%$ of trans-caryophyllene. Their results confirm the presence of some of the compounds identified in the essential oil from $O$. vulgare discussed herein, although the quantities were different.

Similar results were reported by Cleff et

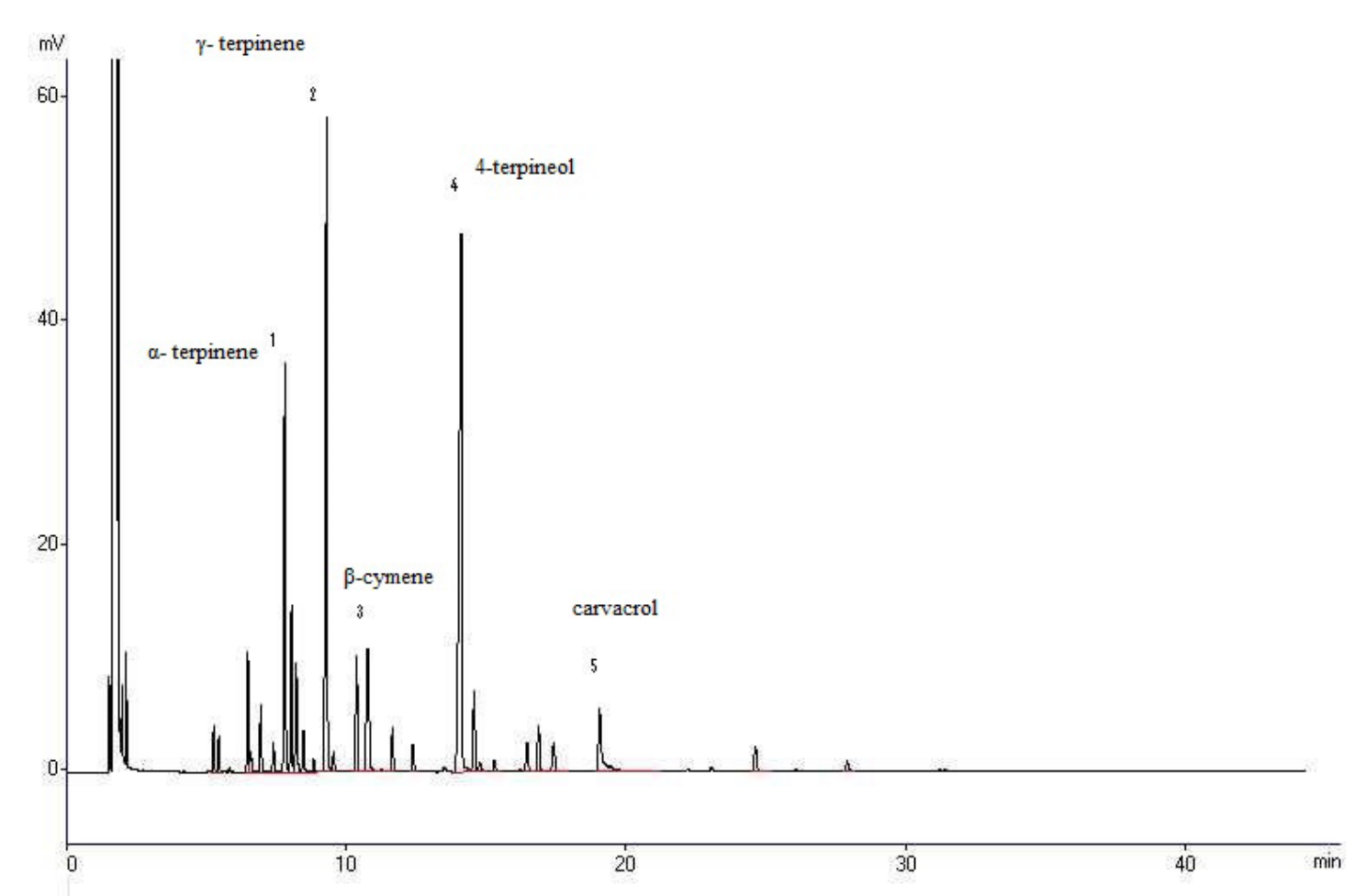

FIGURE 1. Chromatogram of the essential oil from O. vulgare. al. (2010). They found 4-terpineol to be the major constituent, followed by $\mathrm{Y}$-terpinene, thymol, a-terpinene, linalool, p-cymene, a-terpineol, and carvacrol. However, they observed a higher concentration of thymol than carvacrol. In a previous study, Sartoratto et al. (2004) found thymol (38\%), 4-terpineol (33.3\%) and $\alpha$-terpineol (4.25\%) to be the major components. These values differ considerably from the concentration of thymol in the present sample, where it was not among the principal compounds identified.

Differences in the composition of essential oils can occur because of the growing season, genetic factors, such as the occurrence of chemotypes, and extrinsic factors. The environment in which the plant grows and the forms of cultivation significantly influence the composition of the essential oil.

The compounds identified in the essential oil from A. sativum are presented in Table 2.

The chromatogram obtained for $A$. sativum is presented in Figure 2.

The main constituents identified and quantified from the essential oil of $A$. sativum were diallyl trisulfide (38.81\%), diallyl disulfide $(25.23 \%)$, methyl allyl trisulfide (12.52\%). These compounds were identified by comparing the Kovats indexes. Martín-Lagos, Serrano \& Lopez (1995) observed 2-vinyl-4(H)-1,3 (839 mg $100 \mathrm{~g}^{-1}$ ) to be the major compound present in garlic oil, dimethyl trisulfide

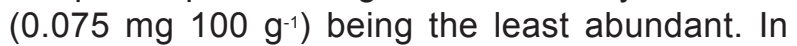
addition, the 2-vinyl-4(H)-1,3-dithiin, diallyl disulfide, 
TABLE 2. Principal compounds identified in the essential oil from A. sativum.

\begin{tabular}{ccccc}
\hline Peak & $\begin{array}{c}\text { Retention time } \\
(\mathbf{m i n})\end{array}$ & IKcal ${ }^{1}$ & Compound & Mean concentration (\%) \\
\hline 1 & 2.07 & 1451 & Not identified & 5.64 \\
2 & 3.79 & 918 & Not identified & 8.35 \\
3 & 4.923 & 867 & Not identified & 3.76 \\
4 & 9.965 & 1085 & Diallyl dissulfide & 25.23 \\
5 & 12.272 & 1145 & Methyl allyl trisulfide & 12.53 \\
6 & 19.380 & 1311 & Diallyl trisulfide & 38.81 \\
\hline
\end{tabular}

IIKcal - Kovats indexes

3-vinyl-4(H)-1,2-dithiin and allyl methyl disulfide were encountered. These results differ from those obtained in the present study. The only similarity with the present study was the presence of diallyl disulfide, which was the second most abundant constituent in the oil samples analyzed.

The inhibition halos for the $S$. Choleraesuis 6539 and $P$. aeruginosa ATCC 15442 bacteria, induced by the essential oils from $O$. vulgare and $A$. sativum, were measured and demonstrated an inhibitory effect for these oils, except for the case of $A$. sativum oil with $P$. aeruginosa. The results are described in Table 3.

It may be inferred that the essential oil from oregano has antibacterial activity against the species tested. The Minimum Inhibitory Concentration (MIC) for both $S$. Choleraesuis and $P$. aeruginosa was $15.62 \mathrm{mg} \mathrm{mL}^{-1}$.

Pereira et al. (2008) showed that the essential oil from $O$. vulgare was effective against $E$. coli and $S$. aureus at all the concentrations tested.

Unlike the findings of the present study, Ernandes \& Garcia-Cruz (2007) found that oregano presented the lowest activity against the pathogens tested when they studied several essential oils. It is noteworthy, however, that, although the inhibitory effect was smaller, it was present at all the concentrations tested. Souza et al. (2006) evaluated

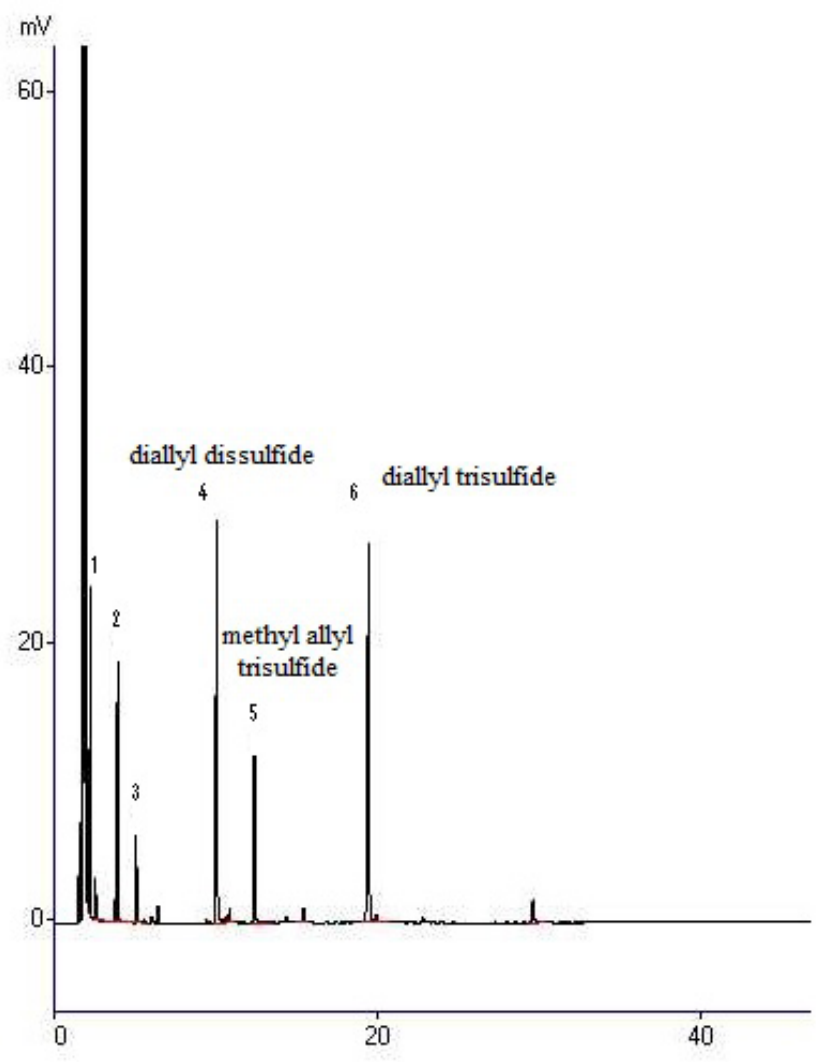

FIGURE 2. Chromatogram of the essential oil from A. sativum. 
the antibacterial activity of the essential oil from $O$. vulgare against various Gram-positive and Gramnegative spoilage and/or pathogenic bacteria in food, including those bacteria investigated in the present study. The results demonstrated a strong antibacterial activity of the essential oil, as indicated by large growth-inhibition zones $(30-37 \mathrm{~mm})$. The MIC values oscillated between 20 and $40 \mu \mathrm{L} \mathrm{mL}^{-1}$ for most bacteria.

The garlic oil did not inhibit the growth of $P$. aeruginosa. The MIC for $S$. Choleraesuis was 62.5 $\mathrm{mg} \mathrm{mL}^{-1}$. Packer \& Luz (2007) found that samples of garlic oil showed no bacteriostatic or fungistatic activity against the microorganisms tested, including $P$. aeruginosa, E. coli and S. aureus. However, the results presented in Tables 4 and 5 demonstrate that the oil possesses fungitoxic activity.

Inhibition of mycelial growth of the A. flavus, $A$. niger and $P$. simplicissimum fungi caused by the essential oil from oregano occurred at concentrations of $0.10,0.03$ and $0.05 \mathrm{mg} \mathrm{mL}^{-1}$, respectively, which are considered to represent the MIC. The oregano oil presented bacteriostatic and fungistatic activity against the microorganisms surveyed.

Recent studies of Carmo et al. (2008) evaluated the efficacy of the essential oil of $O$. vulgare against the growth of some species of Aspergillus (A. flavus, A. parasiticus, $A$. terreus, $A$. ochraceus, $A$. fumigatus and $A$. niger). They observed that it presented a strong activity against the species of the Aspergillus genus, inhibiting the mycelial growth of all the strains of fungi tested. MIC values ranged between 80 and 20 $\mu \mathrm{L} \mathrm{mL}-1$, with a $\mathrm{MIC}_{50}$ of $40 \mu \mathrm{L} \mathrm{mL-1}$. Moreover, the essential oil was able to inhibit the germination of fungus spores when tested at concentrations of 80 and $40 \mu \mathrm{LL}^{-1}$.

The garlic oil exhibited inhibitory activity at the $0.03 \mathrm{mg} \mathrm{mL}^{-1}$ concentration. Thus, this oil inhibited mycelial growth at all the concentrations evaluated. Viegas et al. (2007) evaluated the in vitro toxicity of the essential oil of $A$. sativum against fungi of the $A$. flavus group isolated from peanut crops. They observed that the oil promoted inhibition zones ranging from 7.0 to $15.0 \mathrm{~mm}$. However, these halos were greater than $12.0 \mathrm{~mm}$ for $34 \%$ of the isolates tested. These results illustrate a similarity between the two studies with respect to the inhibitory action of the oil against $A$. flavus.

Souza et al. (2004) investigated the in vitro effect of the essential oil of garlic against the Rhizopus sp., Penicillium spp. Eurotium repens and Aspergillus niger fungi isolated from old bread. The oil was observed to inhibit the mycelial growth of all the fungi except Rhizopus sp., whose growth was inhibited only at the highest concentration tested. These results confirm those of previous studies that have demonstrated the antimicrobial and medicinal properties of these spices.

\section{CONCLUSION}

The oregano and garlic oils significantly inhibited the growth of the bacteria and fungi studied,

TABLE 3. Mean diameters of the inhibition halos showing the effect of the essential oils from $O$. vulgare and $A$. sativum on the growth of $S$. Choleraesuis and $P$. aeruginosa submitted to different concentrations of the oils.

\begin{tabular}{|c|c|c|c|c|}
\hline \multicolumn{5}{|c|}{ Halo $(\mathrm{cm})^{1}$} \\
\hline \multicolumn{3}{|c|}{ O. vulgare } & \multicolumn{2}{|l|}{ A. sativum } \\
\hline $\begin{array}{l}\text { Concentrations } \\
(\mu \mathrm{g} \mathrm{mL}-1)\end{array}$ & S. Choleraesuis & P. aeruginosa & S. Choleraesuis & $P$. aeruginosa \\
\hline 1.95 & $0.00 \mathrm{a}$ & $0.00 \mathrm{a}$ & $0.00 \mathrm{a}$ & $0.00 \mathrm{a}$ \\
\hline 3.90 & $0.00 \mathrm{a}$ & $0.00 \mathrm{a}$ & $0.00 \mathrm{a}$ & $0.00 \mathrm{a}$ \\
\hline 7.81 & $0.00 \mathrm{a}$ & $0.00 \mathrm{a}$ & $0.00 \mathrm{a}$ & $0.00 \mathrm{a}$ \\
\hline 15.62 & $0.50 \mathrm{~b}$ & $0.50 \mathrm{~b}$ & $0.00 \mathrm{a}$ & $0.00 \mathrm{a}$ \\
\hline 31.25 & $0.60 \mathrm{c}$ & $0.65 b$ & $0.00 \mathrm{a}$ & $0.00 \mathrm{a}$ \\
\hline 62.5 & $0.66 \mathrm{~d}$ & $0.75 \mathrm{c}$ & $0.50 \mathrm{~b}$ & $0.00 \mathrm{a}$ \\
\hline 125 & $0.68 d$ & $0.88 \mathrm{c}$ & $0.61 \mathrm{~b}$ & $0.00 \mathrm{a}$ \\
\hline 250 & $0.76 \mathrm{~d}$ & $0.90 \mathrm{c}$ & $0.71 \mathrm{~b}$ & $0.00 \mathrm{a}$ \\
\hline 500.00 & $0.70 \mathrm{~d}$ & $0.91 \mathrm{c}$ & $0.91 \mathrm{c}$ & $0.00 \mathrm{a}$ \\
\hline Chloramphenicol & $1.83 \mathrm{e}$ & $1.48 \mathrm{~d}$ & $1.58 \mathrm{~d}$ & $0.95 \mathrm{~b}$ \\
\hline CV (\%) & 8.66 & 19.48 & 29.27 & 16.64 \\
\hline
\end{tabular}

${ }^{1}$ Means followed by the same letter do not differ significantly at $5 \%$ of probability by the Scott-Knott test. ${ }^{* *} \mathrm{Chloramphenicol}\left(100 \mu \mathrm{g} \mathrm{mL}{ }^{-1}\right)$ 
TABLE 4. Mean diameters of the inhibition halos showing the effect of the essential oil from $O$. vulgare on the growth of $A$. flavus, $A$. niger and $P$. simplicissimum submitted to different concentrations of the oil.

\begin{tabular}{cccc}
\hline \multicolumn{3}{c}{ Halo $(\mathbf{c m})^{1}$} \\
\hline Concentrations $\left(\boldsymbol{\mu g} \mathbf{~ m L}^{-1}\right)$ & A. flavus & A. niger & P. simplicissimum \\
\hline TA & $0.00 \mathrm{a}$ & $0.00 \mathrm{a}$ & $0.00 \mathrm{a}$ \\
TR & $0.00 \mathrm{a}$ & $0.00 \mathrm{a}$ & $0.00 \mathrm{a}$ \\
0.03 & $0.00 \mathrm{a}$ & $23.07 \mathrm{~d}$ & $0.00 \mathrm{a}$ \\
0.05 & $0.00 \mathrm{a}$ & $19.48 \mathrm{~d}$ & $19.16 \mathrm{~b}$ \\
0.07 & $0.00 \mathrm{a}$ & $11.79 \mathrm{~b}$ & $28.33 \mathrm{c}$ \\
0.10 & $10.00 \mathrm{~b}$ & $21.02 \mathrm{~d}$ & $33.33 \mathrm{c}$ \\
0.12 & $10.00 \mathrm{~b}$ & $7.69 \mathrm{~b}$ & $42.50 \mathrm{~d}$ \\
0.14 & $26.66 \mathrm{~d}$ & $8.20 \mathrm{~b}$ & $60.00 \mathrm{e}$ \\
0.16 & $20.00 \mathrm{c}$ & $14.35 \mathrm{c}$ & $59.16 \mathrm{e}$ \\
0.18 & $20.00 \mathrm{c}$ & $11.27 \mathrm{~b}$ & $73.33 \mathrm{f}$ \\
\hline CV $(\%)$ & 42.13 & 20.94 & 10.95 \\
\hline
\end{tabular}

${ }^{1}$ Means followed by the same letter do not differ significantly at $5 \%$ of probability by the Scott-Knott test.

TABLE 5. Mean diameters of the inhibition halos showing the effect of essential oil from garlic on the growth of A. flavus, A. niger and $P$. simplicissimum submitted to different concentrations of the oil*.

\begin{tabular}{lccc}
\hline & \multicolumn{3}{c}{ Halo $(\mathrm{cm})^{1}$} \\
\hline $\begin{array}{l}\text { Concentrations } \\
\left(\mu \mathrm{g} \mathrm{mL}^{-1}\right)\end{array}$ & A. flavus & A. niger & Penicillium \\
\hline TA & & & \\
TR & $0.00 \mathrm{a}$ & $0.00 \mathrm{a}$ & $0.00 \mathrm{a}$ \\
0.03 & $0.00 \mathrm{a}$ & $0.00 \mathrm{a}$ & $0.00 \mathrm{a}$ \\
0.05 & $6.00 \mathrm{~b}$ & $3.63 \mathrm{~b}$ & $35.00 \mathrm{~b}$ \\
0.07 & $14.66 \mathrm{c}$ & $9.08 \mathrm{c}$ & $75.00 \mathrm{c}$ \\
0.10 & $21.33 \mathrm{~d}$ & $9.69 \mathrm{c}$ & $100.00 \mathrm{~d}$ \\
0.12 & $40.00 \mathrm{e}$ & $13.33 \mathrm{~d}$ & $100.00 \mathrm{~d}$ \\
0.14 & $41.33 \mathrm{e}$ & $13.93 \mathrm{~d}$ & $100.00 \mathrm{~d}$ \\
0.16 & $42.00 \mathrm{e}$ & $15.14 \mathrm{~d}$ & $100.00 \mathrm{~d}$ \\
0.18 & $20.00 \mathrm{c}$ & $31.51 \mathrm{e}$ & $100.00 \mathrm{~d}$ \\
\hline CV (\%) & $20.00 \mathrm{c}$ & $43.63 \mathrm{f}$ & $100.00 \mathrm{~d}$ \\
\hline
\end{tabular}

${ }^{1}$ Means followed by the same letter do not differ significantly at $5 \%$ of probability by the Scott-Knott test.

thereby confirming the antibacterial and antifungal efficiency. The oil of $O$. vulgare was the most effective against the microorganisms evaluated.

\section{ACKNOWLEDGEMENT}

The authors thank the Conselho Nacional de Desenvolvimento Científico e Tecnológico (CNPq) for the first author's scholarship, and the Fundação de Amparo à Pesquisa do Estado de Minas Gerais (FAPEMIG) for the financial support. 
Components by Gas Chromatography/Mass Spectrometry - 4 edition. Carol Stream: Allured, 2007. 804p.

CARMO, E.S.; LIMA, E.O.; SOUZA, E.L. The potential of Origanum vulgare L. (Lamiaceae) essential oil in inhibiting of some food-related Aspergillus species. Brazilian Journal of Microbiology, 39, 362-367, 2008.

CLEFF, M.B. et al. In vitro activity of origanum vulgare essential oil against candida species. Brazilian Journal of Microbiology , 41, 116-123, 2010.

ERNANDES, F.M.P.G.; GARCIA-CRUZ, C.H. Atividade antimicrobiana de diversos óleos essenciais em microrganismos isolados do meio ambiente. Boletim CEPPA, 25(2), 193-206, 2007.

FERREIRA, D.F. Análises estatisticas por meio do Sisvar para o Windows versao 4.0. Programas e Resumos da Reunião Anual da Regiao Brasileira da Sociedade Internacional de Biometria, Sao Carlos: UFSCar, 45, 255-258, 2000.

KIZIL, S.; SOGUT, T. Investigation of antibacterial effects off spices. Crop Research, 3(1), 86-90, 2003.

LINDSEY, K.; STANDEN, J.V. Growth inhibition of plant pathogenic fungi by extracts of Allium sativum and Tulbaghia violacea. South African Journal of Botany, 70(4), 671-673, 2004.

MARTÍN-LAGOS, A.M.; SERRANO, O.; LOPEZ, R. Determination of organic sulphur compounds in garlic extracts by gas chromatography and mass spectrometry. Food Chemistry, London, v. 53, n. 3, p. 91-93, 1995.

National Committee for Clinical Laboratory Standards. NCCLS. Perfomance Standards for Antimicrobial Disk Susceptibility Tests; Approved Standard. $8^{\text {th }}$ ed. Wayne: NCCLS. (NCCLS document M2-A8), 2003.

OGUNWANDE, I. A.; OLAWORE, N.O.; EKUNDAYO, O.; WALKER, T.M.; SCHMIDT, J.M.; SETZER, W. N. Studies on the essential oils composition, antibacterial and cytotoxicity of Eugenia uniflora L. The International Journal of Aromatherapy, Amsterdam, v. 15, n. 3, p.
147-152, 2005

PACKER, J.F.; LUZ, M.M.S. Método para avaliação e pesquisa da atividade antimicrobiana de produtos de origem natural. Revista Brasileira de Farmacognosia, 17(1): 102-107, 2007.

PASIN, L.A.A.P.; ABREU, M.S.; CHALFOUN, S.M.; PÁDUA. T.R.P. Efeito de micronutrientes na população fúngica associada a grãos de café (Coffea arábica L.) Ciência e Agrotécnica, 26, 918-926, 2002.

PEREIRA, A.A. et al. Caracterização química e efeito inibitório de óleos essenciais sobre o crescimento de Staphylococcus aureus e Escherichia coli. Ciência e Agrotécnica, 32(3), 887-893, 2008.

PIMENTEL, F.A. et al. A convenient method for the determination of moisture in aromatic plants. Química Nova, 29(2), 373-375, 2006.

SARTORATTO, A. et al. Composition and antimicrobial activity of essential oil from aromatic plants used in Brazil. Brazilian Journal of Microbiology, 35, 275280, 2004.

SIQUI, A.C. et al. Óleos essenciais - potencial antiinflamatório. Biotecnologia, Ciência e Desenvolvimento, 16, 38-43, 2000.

SOUZA, S.M.C. et al. Avaliação de óleos essenciais de condimentos sobre o desenvolvimento micelial de fungos associados a produtos de panificação. Ciência e Agrotécnica, 28(3), 685-690, 2004.

SOUZA, E.L.; STAMFORD, T.L.M.; LIMA, E.O. Sensitivity of spoiling and pathogen food-related bacteria to Origanum vulgare L. (Lamiaceae) essential oil. Brazilian Journal of Microbiology, 37, 527-532, 2006.

SRIDHAR, S.R. et al. Antifungal activity of some essential oils. Journal of Agricultural Food Chemistry, 51, 7596-7599, 2003.

VIEGAS, E.C. et al. Toxicidade de óleos essenciais de alho e casca de canela contra fungos do grupo Aspergillus flavus. Horticultura Brasileira, 23(4), 915-919, 2007. 